\title{
Investigation into Mall Visitation Motivation and Demographic Idiosyncrasies in Ghana
}

\author{
Thomas Anning-Dorson*, Adelaide Kastner and Mohammed Abdulai Mahmoud
}

University of Ghana Business School, Department of Marketing and Customer Management

\begin{tabular}{|c|c|}
\hline CHRON I C LE & A B S T RACT \\
\hline $\begin{array}{l}\text { Article history: } \\
\text { Received September } 15,2012 \\
\text { Received in revised format } \\
20 \text { December } 2012 \\
\text { Accepted } 20 \text { December } 2012 \\
\text { Available online } \\
\text { December } 242012 \\
\text { Keywords: } \\
\text { Shopping motivation } \\
\text { Ghanaian shoppers } \\
\text { Shopping behaviour } \\
\text { Shonnor domooranh. }\end{array}$ & $\begin{array}{l}\text { This paper aims to investigate shoppers' motivations for visiting the mall in respect of their } \\
\text { demographic characteristics. The study was Cross-sectional and adopted the quantitative } \\
\text { method. Structure questionnaire was used to collect data through a mall intercept approach. } \\
\text { Factor analysis was conducted to determine the mall visitation motivations of shoppers and } \\
\text { Chi-square test and regression analysis used to help answer the research questions. The paper } \\
\text { found eight (8) key mall visitation motivations attract Ghanaian shoppers. Escapism influences } \\
\text { the shoppers most, followed by pleasure flow, safety, aesthetic and architectural leisure, } \\
\text { respectively. The least motivational factor is exploration. The result suggests that shoppers in } \\
\text { Ghana are most likely to see the mall as an escape route from their daily hectic conditions and a } \\
\text { place for relaxation. }\end{array}$ \\
\hline
\end{tabular}

\section{Introduction}

Generalizations research findings on shopping centers outside ones context of study are always limited due to the differences in consumers and retail formats available in various countries and geographical locations (Carpenter, 2008). Studies across the globe on retail shopping environment has substantially concentrated in the Western context (Ahmed et al., 2007) leaving the less developed ones who are also of managerial and theoretical significance like Africa unattended. Ghana which is one of the fastest growing economies in the world (World Bank Report) has in recent times seen development of malls and shopping centers which hitherto was non-existent to confirm the growth of the economy. Changing lifestyles and shopping behavior, which is emerging from this economic and infrastructural development affords the researchers the opportunity to update literature on shopping behaviour with empirical perspectives from Africa. As the shopping mall is considered a modern adaptation of the historical African marketplace, there are bound to be different motivations towards the mall.

*Corresponding author.

E-mail addresses: thomasdorson@gmail.com (T. Anning-Dorson) 
Research regarding consumer shopping behaviour first found wide recognition among marketing scholars in 1972, through Tauber's (1972) seminal article, investigating the question "Why do people shop?" Since, then, shopping behaviour has emerged as one of the key constructs of contemporary research in retail marketing and consumer behaviour, discussed in numerous empirical (Dholakia, 1999) and conceptual scholarly articles (Woodruffe-Burton et al., 2002), doctoral dissertations (Perner, 1998), as well as marketing textbooks (McGoldrick, 2002). In recent times scholars such as Hunter, (2006); Rajamma et al. (2009); Soars, (2009) and Beynon, (2010) have dealt well with the subject mostly centered in the developed context while the Sub-Saharan Africa has had less consideration. Retailers and manufacturers are very interested in how shoppers make their purchase decisions, as well as when, why and whether a shopping trip leads to a purchase. Such information is critical in formulating marketing strategy (Kotler a\& Keller, 2006) and retailing planning (Levy \& Weitz, 2007). Marketing literature has revealed that many factors may affect shoppers' purchase decisions, including individual and psychological characteristics, cultural, social and environmental variables and promotional strategies.

Extensive efforts have been made in investigating the buyer behaviour impact on shoppers' buying decisions. For example, previous studies indicate that people have various motivations for shopping: some for a purely utilitarian purpose, others for hedonistic reasons (Arnold and Reynolds, 2003; Babin et al., 1994). It must however be indicated that these motivations may be affected by contextual factors as most of the studies are done in the developed context. These various motivations for shopping trip is defined by a consumer may affect his/her behaviour. These shopping motivations can be highly influenced by the shopping environment such as the mall which is the face of the retail modernization. The major research objective is to look into the critical mall attributes that serve as mall visitation motivations at the mall in an emerging economy and their demographic idiosyncrasies on patronage.

According to Tauber (1972), consumer behaviour consists of three distinct activities: shopping, buying, and consuming. Considerable progress has been achieved in identifying behavioural dimensions of buying and a number of theories on buying behaviour have been postulated. However, much less is known about the determinants of consuming and shopping behaviour (Ahmed et al., 2007) and this study also attempt to provide empirical support for the limited literature. This study is also justified on the basis that the development of modernized retailing literature is still in the early development state and that this study contributes to the empirical literature by giving the version of the developing context which is of managerial and theoretical substance. The rest of the paper presents a literature review and conceptual framework, methodology, presentation of results, discussion of findings and conclusion and implications for future research.

\section{Literature review and conceptual development}

The mall is a collection of independent retail stores, services, and a parking area, which is conceived, constructed, and maintained by a separate management firm as a unit. As the world first fully enclosed shopping mall was born in 1950s in America, in the last five decades, shopping malls have mushroomed all over the world (see Ahmed et al., 2007; Reardon et al., 2007). The mall design has evolved from an open air, to a fully enclosed building with air conditioners and containing amusement park, restaurants, banks, theaters, professional offices, service stations etc. The shopping malls compete from the product offerings which include excellence services, competitive prices, and attractive promotions to exciting mall atmospheres. Consumers are also more knowledgeable, with tastes, preferences and shopping behaviour becoming more sophisticated because of higher disposable incomes and the impact of globalization (Chan \& Yap, 2004).

Retail management and shopping center developers continually attempt to respond to changing shopper preferences and demands. They are aware that many consumers choose shopping locations based on their appeal as a one-stop center. Underlying such shopper choices is the need to balance 
demands on shoppers' available time to shop, their ability to travel from center to center, and their willingness to do so. Today, shopping malls have emerged as places for social gatherings, weekend family outings and more. According to $\mathrm{Ng}$ (2003), shopping malls have tailored themselves to become not only a centre for shopping but also a community centre for social and recreational activities. Shopping itself is no longer confined to purchasing of goods but has evolved into a form of recreation. Visiting shopping mall has become a family leisure activity rather than a purely economic activity (Millan \& Howard, 2007). Shoppers are looking for a variety of merchandise, exciting promotions, food and even entertainment. As a result, shopping malls have usurped squarely the function of olden-day community halls, coffee shops or shady trees (Baharun, 1997).

Several studies have attempted to identify shoppers' underlying motives and the relationship between these motives and shoppers' behaviour (e.g. Jin \& Kim, 2003; Tauber, 1972; Westbrook \& Black, 1985). Shopping motivations can be defined as "the drivers of behaviour that bring consumers to the marketplace to satisfy their internal needs" (Jin \& Kim, 2003, p. 399). Bloch et al. (1994) for instance identified seven dimensions of shopping malls that collectively explain consumers' motives for visiting malls. These dimensions were: aesthetics, escape, flow, exploration, role enactment, social and convenience. Bellenger et al. (1977) in their study discovered four basic dimensions (quality of the center, presence of related services, variety under one roof and economic convenience). Wilhelm and Mottner's (2005) attributes consisted of teen friendliness, number of cool mall stores, number of different kinds of mall stores, number of entertainment options, number of sports/play options and mall design. Newberry et al.'s (2003) research identified seven dimensions which, among others, included décor, atmosphere, appearance and cleanliness.

According to El-Adly (2007), the attractiveness of a mall is attributable to six factors including comfort, entertainment, diversity, mall essence, convenience and luxury. Likewise, in prior research, it is not uncommon for an attribute such as atmosphere to be labeled under "quality of center" in one study (Bellenger et al., 1977) but under "facilities" in another study (Wong et al., 2001). Or price be an indicator of "quality and variety" in one study (Wong et al., 2001) but be related to "economic convenience" dimension in the other study (Bellenger et al., 1977). Or variety of stores be an indicator of "value assortment" factor in one study (LeHew et al., 2002) but belong to "mall essence" factor in another study (El-Adly, 2007).

\subsection{Conceptual framework}

From the forgoing literature review, there are some mall visitation motivations discussed and used by different scholars. This study based on the clear and consistent motives for going shopping has identified the following five mall shopping motivations as they try to capture all the discussed motives that run through the various studies. These motives are discussed to serve as a guide in the development and the measurement of the scales and to check the applicability in the Ghanaian context.

Aesthetic and architectural motivation: malls aesthetic and architectural offer visitors the advantage of climatic comfort and freedom from the noise and traffic that categorizes other shopping venues since a "noisy" environment creates a different image than is characterized by silence or soft background music. Ahmed et al. (2007) contend that architectural elements are being used by developers to increase the drama of mall interiors and to satisfy consumer-seeking sensory stimulation. The aesthetics of the mall inculcates the internal designs that attract the visitor's sensory stimuli. Design features (e.g. high ceilings, flooring/carpeting, architecture, interior landscaping, store layout), as well as physical facilities (elevators, air-conditioning, and washrooms) all impact assessments by consumers. According to Lui (1997), modern mall interiors have evolved from "comfortable" to architecturally rich, with lavish materials and sophisticated design elements. Interior design actually continues the mall's image-fostering process (Loudon \& Bitta, 1993). 
Wakefield and Baker (1998) in their study found that architectural design had the strongest positive influence on mall excitement, while interior décor had the strongest positive effect on desire to stay. Light and color has been found as having impact on the feeling of spaciousness and serenity and signs in bright colors create excitement as found by Solomon (1994). Mall developers are finding ways of appealing to the sensuality of shoppers which are offered in the mall's aesthetics.

Escapism (Getaway) motivation: Ahmed et al. (2007) state that the mall offer access to new experiences as a break from the consumer's hectic activities and the shoppers are attracted by the mall's atmospherics which is seen as an offer for relief from boredom or loneliness. Underhill, (2005) intimated this by stating that many malls are currently offering high level of sensory stimulation. As the mall offer the visitor entertainment which is mostly free or low cost, visitors can have family entertainment in a non-formal manner without advance preparation. Malls therefore offer its patrons pastime opportunities to get away from the hectic daily hassle and it has become one of the few places where people seek solace whenever they are in need of "live". Ahmed et al., (2007) shopping malls represent a unique form of shopping environment and have become a social place in which people converge to engage not only in buying activities, but also in social activities, such as going to a movie, having food or a meal out, getting together with friends or family, hair styling, etc.

Flow and Exploration motivation: Flow has been described as a pleasurable state of absorption that is associated with losing track of time (Bloch et al., 1994; Lui, 1997) while Ahmed et al. (2007) describes it as a rare and desirable state the shopper would want to get to. Thus, one may speculate that the achievement of flow while in a mall may encourage continuation among consumers enthusiastic about shopping in mall (Ahmed et al., 2007). The flow attribute of the mall can make visitors lose track of time since they are normally isolated from cues of time and whether in that enclosed environment. The more sufficient the mall atmosphere is, the high propensity of the hours gliding by without the mall visitor noticing. On exploration, Wakefield and Baker (1998) discovered that gathering information by exploring new products or stores was a perceived benefit of the mall experience. Tauber (1972) in his seminal article described the exploration motive of the mall as the learning of new trends, technology, style and fashion. This was corroborated by Wakefield and Baker (1998) that the exploration attribute of the mall taps into consumers' desire for variety. Having a variety of stores or mix of tenants that work well together to meet the needs of many types of customers, including those valuing exploration, will enhance the performance of the entire shopping mall (Kaufman, 1996).

Socialization, leisure and pleasure motivation: shopping in whatever form it takes offer shoppers opportunity to leisure and pleasure which otherwise cannot be offered at home. Mall visits can create new acquaintances and meeting of both new/old friends and sometimes attract the opposite sex. Thus, social variables offering the benefit of affiliation with others also make malls attractive leisure sites (Ahmed et al., 2007). Tauber (1972) and (Wakefield \& Baker, 1998) suggested that an important pleasing aspect of shopping includes the opportunity for social interaction with friends, family, or even strangers that one encounters in a shopping location. People will shop where they feel wanted and will even pay a little more for the privilege (Underhill, 1999). Leisure is any satisfying experience (Torkildsen, 1992) and the mall visitor will always want and shopping may or may not be a leisure or recreational activity. For instance, leisure's promise according to Howard, 2007 is that: . . . a deep sense of appreciation envelopes us and lifts us to a higher plane, where we discover that there is peace and beauty and joy in the world. That may carry over into increasing appreciation of life itself (p. 663). From a sociological perspective, malls have become community centers, offering visitors common recreational attractions, e.g. music, movies, games, and dining out (Ahmed et al., 2007). Many researchers have asserted that, shopping at the mall is viewed at a recreational activity (Rintamaki et al., 2006; Sit et al., 2003; Dennis et al., 2005). This is supported by Dholakia (1999) by saying that the shoppers have a social motive and its very important since "shopping is a spectacle in which one is both performer and spectator. . . it is seeing and being seen, meeting and being met, a 
way of interacting with others'. Chetthamrongchai and Davies (2000) also advanced that shopping may even be a very enjoyable use of time without the purchase of goods or services for recreational shoppers.

Convenience and external motivation: Convenience is also important to anti-shoppers - consumers who make fewer mall visits and fewer purchases (Loudon \& Bitta, 1993). Anti-shoppers perceive shopping as stressful and, therefore, a task that is to be completed quickly. Anti-shoppers will prefer malls or stores where they can get in and out quickly. Convenience of location and product assortments offered will be key criteria for these consumers (Ahmed et al., 2007). Shoppers will tend to favor centers that enable the completion of all essential shopping and related tasks at one concentrated location (Kaufman, 1996). According to Kaufman (1996), many shoppers select shopping areas based on hours of operation and travel time. Retail location theory also posits that consumers prefer to shop as close to home as possible. Loudon and Bitta (1993) found that consumers were very convenience-oriented; they disliked spending a lot of time finding a parking space and trekking from one end of a mall to another.

De Juan (2004) said that accessibility has been traditionally associated with such proximity indicators as distance to home or work or driving time to the shopping venue though recent thinking separates it from locational convenience (Haytko \& Baker, 2004). Included in accessibility as a distinct patronage dimension are such attributes as ease with which shoppers can get into and out of a mall and find their way around once they are in the mall (Dogu \& Erkip, 2000; Haytko \& Baker, 2004). Based on related research, Yava and Babakus, 2009 contend that additional attributes may be closely associated with accessibility, one they considered as parking facilities, security provision, feeling of confort and adequate and easy time parking.

Several researchers have posited that demographic characteristics of customers affect their purchasing behavior (e.g. Raju, 1980; Wood, 1998), however, this relationship is currently considered unclear as research findings have been found to be controversial (e.g. Jin \& Kim, 2001; Mai \& Zhao, 2004; Mitchell \& Walsh, 2004).With the aim of assessing the demographic idiosyncrasies in respect of mall visitation motivation, the study will test the association of sex, age, educational status, employment status, marital status and monthly income against the various mall visitation motivations that will be identifies through exploratory factor analysis. Based on the review above, the study seeks answers to the following questions;

Question 1: What are the mall visitation motivations at the mall in an emerging economy?

Question 2: What is the relationship between shopping motivation and demographic idiosyncrasies of mall visitors?

\section{Question 3: What are the shopping dimensions hierarchy effects on mall visitation?}

\section{Methodology}

This study adopts the deductive approach. Deductive reasoning works from the more general to the more specific. The study begins with thinking up a theory about the topic of interest then narrows down into more specific questions that can be tested (Robson, 1993). This ultimately leads us to be able to test the hypothesis with specific data -- a confirmation (or not) of our original theories (Saunders et. al., 2000; Kumar, 1996; Robson, 1993). The study adopted the survey strategy as it is usually associated with the deductive approach (Saunders et al., 2007). The study was Cross-sectional and adopted the quantitative method of research since quantitative research is commonly used when the purpose is to test hypotheses and generalize the results (Hair et al., 2003; Holme \& Solvang, 1991) as this study sought to do. Data were collected from the Accra Mall and the A\&C Mall which 
are the most prominent malls and seen as the flagship of malls in the country. Structured questionnaire were distributed to visitors of these malls. These questionnaires were Likert in nature for easy fill out and in conformity with previous studies. Shoppers were intercepted at the mall to allow respondents to easily recall activities and give appropriate responses because of environmental influence.

A total of 600 questionnaires were printed and distributed to shoppers of Accra and A\&C shopping malls. Shoppers were intercepted while they were within the mall and requested to help fill the questionnaires. Respondents were asked to fill and return the instruments immediately as it would have been difficult to collect them later. The distributions of the questionnaires were done over a period of four-weeks. A total of 528 were successfully returned as some abundant the questionnaire midway into the filling. However, 467 were usable which were finally used in the final analysis representing a usable response rate of $77.83 \%$.

\section{Results}

The table below shows the demography of the respondents in terms of their sex, age, education level, income, marital status and employment status. From the table, there is more males visit the mall than females as $57 \%$ males as against $42.8 \%$ females were recorded. Most of the people who visit the more are between the ages of 18 and 35 as they had a total of 333 representing $71.4 \%$ of the entire sample.

\section{Table 1}

Demography of Respondents

\begin{tabular}{|c|c|c|}
\hline DEMOGRAPHIC FACTOR & FREQUENCY (N=467) & PERCENTAGE (\%) \\
\hline Sex Male & 266 & 57 \\
\hline Female & 200 & 42.8 \\
\hline Age Less than 18 & 25 & 5.4 \\
\hline $18-25$ & 204 & 43.7 \\
\hline $26-35$ & 129 & 27.7 \\
\hline $36-45$ & 72 & 15.4 \\
\hline 46 and above & 35 & 7.5 \\
\hline \multicolumn{3}{|l|}{ Highest Education Level } \\
\hline Basic & 30 & 6.4 \\
\hline Senior high & 68 & 14.6 \\
\hline Tertiary or more & 346 & 74.1 \\
\hline No formal schooling & 20 & 4.3 \\
\hline \multicolumn{3}{|l|}{ Marital Status } \\
\hline Never married & 257 & 55.0 \\
\hline Married & 201 & 43.0 \\
\hline Divorced/separated/widowed & 9 & 1.9 \\
\hline Employment Status Student & 135 & 28.9 \\
\hline Employed & 308 & 66 \\
\hline Unemployed & 24 & 5.1 \\
\hline \multicolumn{3}{|l|}{ Estimated Monthly Income } \\
\hline $\mathrm{GH} \phi<100$ & 63 & 13.5 \\
\hline GHф100-500 & 153 & 32.8 \\
\hline GH $\varnothing 501-1000$ & 138 & 29.6 \\
\hline $\mathrm{GH} \notin 1001-1500$ & 82 & 17.6 \\
\hline $\mathrm{GH} \not 1501-2000$ & 17 & 3.6 \\
\hline Over GH $₫ 2000$ & 8 & 1.7 \\
\hline
\end{tabular}

As shown in Table 1, most of the respondents representing over $74 \%$ have had tertiary education and therefore did not require further explanation of the questionnaires which normally account for interviewer biases. Only $6.4 \%$ have had basic formal education but did not require much interpretation of the questions to affect their responses. Single in terms of marital status attend the mall than married ones as $43 \%$ of the respondents were married leaving the rest never married; or divorced, separated or widowed. A sizeable portion of the sample representing $66 \%$ were employed 
and therefore deemed to have the purchasing power to visit the mall. However, since most of the respondents were youth as indicated in the age groupings, a quite substantial number of the respondent were students. Again, this can be attributed to the geographical location of the malls as they are located closer to tertiary educational institutions and other schools. Finally in terms of the income of the respondents, a chunk of the respondents representing 32.8\% earn between $\mathrm{GH} \phi 100$ and 500 while another $26.9 \%$ earn between GHф501 and 1000 and $22.9 \%$ also earning more than GH $\varnothing 1000$ showing that those considered in the study had purchasing power and therefore visit the mall with the possibility of spending.

\subsection{Factor Analysis}

According to the literature, there are number of scale measures for mall visitation. This study sought to maximize the usefulness of these scales and therefore considered a number of them amid additions from the researcher. Where there were inconsistencies in the scales from different scholars, the researcher rephrased the questions to make it more relevant to the context of the study. The various scholars and their themes regarding mall visitation motivation have been discussed literature review section of the study which paved way for factor analysis to determine what the MVM are in Ghana. In total, thirty-four (34) items were used as a measurement for mall visitation motivation (MVM). Respondents were to indicate their level of agreement for all of the items used for MVM on a fivepoint Likert scale where strongly agree represented the highest level of agreement with 5-points and 1-point for strongly disagree and a mid level of 3-points representing neither agree nor disagree. In accordance with best practices as suggested by Tull and Howkins (1994), Parasuraman et al., (1998), Churchil (1995) and Dabholkar et al., (1996) exploration of the underlying structure of the data carried out through exploratory factor analysis (EFA) and stepwise process suggested by Hair et al. (2006) was followed.

Initial visual assessment of the correlation matrices for mall visitation motivation indicated considerable degree of inter-factor correlation as indicated in table 2. In addition, from the correlation matrices, the Bartlett test of Sphericity (Chi-square $=5527.30, \mathrm{df}=561 ; \mathrm{p}<0.000)$ for Mall Visitation Motivation and Kaiser-Meyer-Olkin (KMO) measure of sampling adequacy indices (value of 0.828) for Mall Visitation Motivation confirmed the appropriateness of the data for EFA. Given that the aim was to identify the minimum portion of the variance of the original items, principal component analysis was selected (Nunnally, 1978) to reduce the number of factors where the Eigen value greater than 1 and a cumulative percentage of variance explained being greater than $50 \%$ were the criteria used in determining the number of factors. On the basis of these criteria, 9 factors were extracted for Mall Visitation Motivation which collectively accounted for a satisfactory $60.05 \%$ of the variance. Furthermore, the communality column in table provides further evidence of the overall significance of the solution.

In order to obtain a clear picture of the structure, the initial solution was rotated and the absence of a compelling analytical or theoretical reason, no prior assumption in terms of factor dependence was made and consequently an oblique rotation was applied to the data (Parasuraman et al., 1988). On the basis of the sample size, the criterion for the significance of the factor loading for the extracted common factor was stipulated to be greater than the absolute value of 0.5 suggested by Hair et al. (2006). Communality was also examined in order to assess how much variance of each item was accounted for by the extracted factors and shed light into possible elimination of items (given the lack of accepted guidelines a cut-off value of 0.3 was used).

Initial analysis through the principal component analysis for MVM produced nine factors as shown in the table below with the Varimax- Rotated Factor Component loadings also showing in table 3 . The nine factors accounted for $60.045 \%$ of the total variance which the first factor accounted for $29.19 \%$. 
Table 2

Principal Component Analysis for Mall Visitation Motivation

\begin{tabular}{|c|c|c|c|c|c|}
\hline Variable & Communality & Factor & $\begin{array}{l}\text { Eigen } \\
\text { value }\end{array}$ & $\begin{array}{l}\text { Percentage } \\
\text { of variance }\end{array}$ & $\begin{array}{l}\text { Cumulative } \\
\text { percent }\end{array}$ \\
\hline $\begin{array}{l}\text { This mall is beautifully designed to attract } \\
\text { people like me }\end{array}$ & .642 & 1 & 7.544 & 22.189 & 22.189 \\
\hline I am attracted by the mall interior beauty & 677 & 2 & 2.323 & 6.831 & 29.020 \\
\hline The store layout and walkways are inviting & .568 & 3 & 2.195 & 6.456 & 35.476 \\
\hline $\begin{array}{l}\text { The environment (i.e. lighting and } \\
\text { decoration) in the malls attracts my } \\
\text { attentions }\end{array}$ & .469 & 4 & 1.892 & 5.564 & 41.040 \\
\hline $\begin{array}{l}\text { When I am alone, bored and need } \\
\text { something to do, the mall is a good place to } \\
\text { go }\end{array}$ & .562 & 5 & 1.587 & 4.667 & 45.706 \\
\hline $\begin{array}{l}\text { When I am stressful, the mall is a good } \\
\text { place to go }\end{array}$ & .695 & 6 & 1.444 & 4.247 & 49.953 \\
\hline I feel relax during my mall visit & .612 & 7 & 1.268 & 3.729 & 53.682 \\
\hline I visit the mall to avoid traffic congestion & .524 & 8 & 1.119 & 3.290 & 56.972 \\
\hline $\begin{array}{l}\text { I visit the mall as a diversion from the } \\
\text { daily routine life }\end{array}$ & .546 & 9 & 1.045 & 3.073 & 60.045 \\
\hline $\begin{array}{l}\text { When I am in the mall, I feel like I am in } \\
\text { another world }\end{array}$ & .547 & & & & \\
\hline $\begin{array}{l}\text { I lose track of time, when I am inside the } \\
\text { mall }\end{array}$ & .639 & & & & \\
\hline $\begin{array}{l}\text { When I leave the mall, I am sometimes } \\
\text { surprised to find out it is dark outside }\end{array}$ & .634 & & & & \\
\hline $\begin{array}{l}\text { The mall is a good place to find out what is } \\
\text { new }\end{array}$ & .617 & & & & \\
\hline $\begin{array}{l}\text { Certain stores in the mall are fun to visit } \\
\text { because they sell products that interest me }\end{array}$ & .699 & & & & \\
\hline $\begin{array}{l}\text { I consider a visit to the mall as a learning } \\
\text { experience. }\end{array}$ & .536 & & & & \\
\hline $\begin{array}{l}\text { I enjoy handling the merchandise and } \\
\text { trying it on }\end{array}$ & .344 & & & & \\
\hline I feel modern by visiting the mall & .577 & & & & \\
\hline $\begin{array}{l}\text { Going to the mall is an enjoyable } \\
\text { experience when I am with friends }\end{array}$ & .452 & & & & \\
\hline I visit the mall to meet new friends & .608 & & & & \\
\hline I feel excited whenever I visit the this mall & .500 & & & & \\
\hline $\begin{array}{l}\text { I enjoy being pampered by attentive } \\
\text { salespeople }\end{array}$ & .806 & & & & \\
\hline $\begin{array}{l}\text { I enjoy talking to other customers and sales } \\
\text { people }\end{array}$ & .813 & & & & \\
\hline I love the sales promotions at the mall & .727 & & & & \\
\hline My going to the mall is a form of a leisure & .612 & & & & \\
\hline $\begin{array}{l}\text { I visit this mall because of its convenient } \\
\text { location }\end{array}$ & .524 & & & & \\
\hline $\begin{array}{l}\text { I visit this mall because it is easier to find a } \\
\text { parking space }\end{array}$ & .605 & & & & \\
\hline The mall store hours are convenient & .538 & & & & \\
\hline $\begin{array}{l}\text { The mall serves as a one-stop shopping } \\
\text { place for me }\end{array}$ & .557 & & & & \\
\hline $\begin{array}{l}\text { I visit this mall for its tenant variety and } \\
\text { product assortment }\end{array}$ & .630 & & & & \\
\hline $\begin{array}{l}\text { I visit this mall for its other complementary } \\
\text { services like cinema, better management } \\
\text { and promotions }\end{array}$ & .521 & & & & \\
\hline $\begin{array}{l}\text { I visit this mall for its better traffic } \\
\text { management around the area }\end{array}$ & .628 & & & & \\
\hline It is a good place to shop with children & .638 & & & & \\
\hline I feel very secure in this shopping mall & .702 & & & & \\
\hline It is very easy to find what I want always & .665 & & & & \\
\hline
\end{tabular}


Table 3

Varimax- Rotated Factor Component Loadings for Mall Visitation Motivation

\begin{tabular}{|c|c|c|c|c|c|c|c|c|c|}
\hline \multirow[b]{2}{*}{ Variable } & \multicolumn{9}{|c|}{ Factors } \\
\hline & 1 & 2 & 3 & 4 & 5 & 6 & 7 & 8 & 9 \\
\hline I enjoy being pampered by attentive salespeople & .868 & .100 & .089 & .113 & .079 & .021 & -.002 & -.034 & .122 \\
\hline I enjoy talking to other customers and sales people & .855 & .059 & .206 & .053 & .097 & .031 & .057 & .049 & .128 \\
\hline I love the sales promotions at the mall & .750 & .028 & -.015 & .081 & .178 & .008 & .304 & .180 & -.034 \\
\hline I feel excited whenever I visit the this mall & .480 & .240 & .371 & .137 & .169 & -.051 & .119 & .047 & .091 \\
\hline I am attracted by the mall interior beauty & .042 & .770 & .172 & .194 & -.013 & .074 & -.077 & .019 & .055 \\
\hline $\begin{array}{l}\text { This mall is beautifully designed to attract people like } \\
\text { me }\end{array}$ & .024 & .708 & .129 & .278 & -.099 & .087 & -.006 & .103 & .137 \\
\hline The store layout and walkways are inviting & .130 & 670 & -.010 & -.078 & .026 & .068 & .277 & .110 & .049 \\
\hline $\begin{array}{l}\text { The environment (i.e. lighting and decoration) in the } \\
\text { malls attracts my attentions }\end{array}$ & .117 & .589 & .092 & .111 & .210 & .072 & .158 & .069 & -.096 \\
\hline $\begin{array}{l}\text { When I leave the mall, I am sometimes surprised to } \\
\text { find out it is dark outside }\end{array}$ & .088 & .197 & .749 & -.010 & .133 & -.006 & .008 & .018 & -.094 \\
\hline I lose track of time, when I am inside the mall & .226 & .119 & .747 & -.014 & .027 & .001 & .105 & -.006 & .058 \\
\hline When I am in the mall, I feel like I am in another world & -.087 & -.108 & .606 & -.011 & -.109 & .339 & .159 & .069 & .058 \\
\hline I visit the mall to meet new friends & .227 & .323 & .548 & .246 & .266 & -.105 & -.055 & .075 & .000 \\
\hline $\begin{array}{l}\text { I visit this mall for its tenant variety and product } \\
\text { assortment }\end{array}$ & .156 & .148 & .054 & .743 & .007 & -.002 & -.033 & .108 & .131 \\
\hline The mall serves as a one-stop shopping place for me & .007 & .087 & -.008 & 649 & .282 & -.059 & .133 & .036 & .164 \\
\hline $\begin{array}{l}\text { I visit this mall for its other complementary services } \\
\text { like cinema, better management and promotions }\end{array}$ & .050 & .175 & .016 & .627 & .044 & .013 & .236 & .127 & -.141 \\
\hline My going to the mall is a form of a leisure & .068 & -.132 & -.137 & .118 & .685 & .194 & .206 & -.044 & -.077 \\
\hline I consider a visit to the mall as a learning experience. & .172 & .285 & .180 & .118 & .545 & .004 & .249 & .139 & .026 \\
\hline I visit the mall as a diversion from the daily routine life & .174 & -.075 & .355 & .147 & .501 & -.007 & .155 & .102 & .277 \\
\hline I visit the mall to avoid traffic congestion & .235 & .091 & .184 & .078 & .494 & .051 & -.216 & .016 & .356 \\
\hline I visit this mall because of its convenient location & .151 & .006 & .121 & .296 & .424 & -.048 & .300 & .102 & .342 \\
\hline I feel modern by visiting the mall & .063 & .143 & .381 & .356 & .398 & -.064 & -.064 & .336 & .027 \\
\hline I enjoy handling the merchandise and trying it on & .315 & .236 & .078 & -.156 & .348 & -.052 & -.154 & .077 & .073 \\
\hline When I am stressful, the mall is a good place to go & -.075 & .077 & .006 & .105 & -.008 & .815 & -.091 & -.004 & .013 \\
\hline I feel relax during my mall visit & .122 & .207 & -.060 & -.210 & .021 & .710 & -.036 & -.020 & -.023 \\
\hline $\begin{array}{l}\text { When I am alone, bored and need something to do, the } \\
\text { mall is a good place to go }\end{array}$ & .001 & -.014 & .142 & .025 & .121 & .706 & .094 & .136 & -.012 \\
\hline $\begin{array}{l}\text { Certain stores in the mall are fun to visit because they } \\
\text { sell products that interest me }\end{array}$ & .153 & .234 & .140 & .022 & .204 & .012 & .741 & .075 & .069 \\
\hline The mall store hours are convenient & .158 & -.051 & .014 & .272 & .056 & .003 & .549 & .200 & .302 \\
\hline $\begin{array}{l}\text { Going to the mall is an enjoyable experience when I } \\
\text { am with friends }\end{array}$ & .009 & .314 & .148 & .311 & -.011 & -.208 & .412 & .054 & -.138 \\
\hline The mall is a good place to find out what is new & .047 & .351 & .272 & .301 & 319 & .156 & .411 & .149 & -.095 \\
\hline I feel very secure in this shopping mall & .188 & .013 & .076 & .116 & -.133 & .068 & .124 & .781 & -.023 \\
\hline It is very easy to find what I want always & -.057 & .175 & .005 & .060 & .189 & .037 & .081 & .761 & .071 \\
\hline It is a good place to shop with children & .097 & .179 & .065 & .432 & .250 & .076 & .085 & .537 & .205 \\
\hline $\begin{array}{l}\text { I visit this mall because it is easier to find a parking } \\
\text { space }\end{array}$ & .000 & .047 & -.020 & -.087 & .053 & -.051 & .151 & .013 & .753 \\
\hline $\begin{array}{l}\text { I visit this mall for its better traffic management around } \\
\text { the area }\end{array}$ & .252 & .044 & .001 & .295 & .075 & .058 & -.073 & .093 & .673 \\
\hline
\end{tabular}

\subsection{Reliability and Internal Consistency}

The internal reliability of the nine factors for mall visitation motivation were analysed through Cronbach's coefficient alpha. As prescribed by Nunally (1968) and Hair et al., (2006), only factors that meet the minimum value of 0.6 were accepted. Also, in order to test the value of the variables that loaded onto the factors, item-to total correlation was set above 0.3 (Parasuraman et al., 1988; Hair et al., 2006). As a result, the factors were re-specified. This was further done to reduce the number of factors. This is consistent with recommendations by Churchil (1995) and Hair et al., (2006) who state that the deletion or merger of a particular statement/item can only be justified when the item to be eliminated or merged are conceptually related with another group of items. Items were eliminated if by merging them with others, there was no improvement in the internal reliability that is no increase in the Cronbach alpha value (Parasuraman, 1988, Hair et al., 2006). 
As per the discussions above, factors 1, 2, 4, 5, 6, 7 and 8 were maintained without alteration for Mall Visitation Motivation. However, an item in factor $3 \mathrm{had}$ item-total correlation figure of less than 3 and was therefore deleted. Factor 9 was deleted due to the fact that its alpha value was lower than 0.6 and the items to total correlation were less than 3. Attempt to add these items to conceptually fit group of factors led to reduction of the alpha value. Upon the revision of the structure of the factors, a further internal consistency was checked the factors named as they conceptually fit. To answer the research question 1 and in accordance with the extent literature there are eight factors that serve as mall visitation motivation in Ghana. They are pleasure, aesthetics and architectural design, flow, leisure (relaxation), convenience, escapism, exploration and safety. These motivations for mall visitation were further checked by their Cronbach alphas which were all more than 0.6 to ensure reliability. The table 4 below shows the details.

\section{Table 4}

Internal Constancy of Revised Structure for Mall Visitation Motivation

\begin{tabular}{|c|c|c|c|c|}
\hline Factor and Item & $\begin{array}{l}\text { Number of } \\
\text { items }\end{array}$ & $\begin{array}{l}\text { Item }- \text { total } \\
\text { correlations }\end{array}$ & $\begin{array}{l}\text { Weighted } \\
\text { mean }\end{array}$ & $\begin{array}{l}\text { Cronbach } \\
\text { Alpha }\end{array}$ \\
\hline Factor 1/Pleasure Motivation & 4 & & 3.55 & 0.831 \\
\hline I enjoy being pampered by attentive salespeople & & .741 & & \\
\hline I enjoy talking to other customers and sales people & & .778 & & \\
\hline $\begin{array}{l}\text { I enjoy the hassle and bustle of stores and in the shopping } \\
\text { mall }\end{array}$ & & .644 & & \\
\hline I feel excited whenever I visit the this mall & & .492 & & \\
\hline Factor 2/ Aesthetics And Architectural Motivation & 4 & & 3.96 & 0.736 \\
\hline $\begin{array}{l}\text { The interior design of the malls usually attracts my } \\
\text { attentions }\end{array}$ & & .546 & & \\
\hline This mall is beautifully designed to attract people like me & & .631 & & \\
\hline I am attracted by the mall interior beauty & & .493 & & \\
\hline $\begin{array}{l}\text { The environment (i.e. lighting and decoration) in the malls } \\
\text { attracts my attentions }\end{array}$ & & .467 & & \\
\hline Factor 3/Flow Motivation & 3 & & 3.32 & 0.725 \\
\hline I lose track of time, when I am inside the mall & & .588 & & \\
\hline When I am in the mall, I feel like I am in another world & & .556 & & \\
\hline I visit the mall to meet new friends & & .427 & & \\
\hline Factor 4/ Convenience Motivation & 3 & & 4.07 & 0.631 \\
\hline I visit this mall for its tenant variety and product assortment & & .455 & & \\
\hline The mall serves as a one-stop shopping place for me & & .497 & & \\
\hline $\begin{array}{l}\text { I visit this mall for its complementary services like cinema, } \\
\text { better management and promotion }\end{array}$ & & .382 & & \\
\hline Factor 5/ Escapism Motivation & 5 & & 3.69 & 0.693 \\
\hline My going to the mall is a form of a leisure & & .351 & & \\
\hline I consider a visit to the mall as a learning experience. & & .431 & & \\
\hline I visit the mall as a diversion from the daily routine life & & .549 & & \\
\hline I visit the mall to avoid traffic congestion & & .417 & & \\
\hline I visit this mall because of its convenient location & & .498 & & \\
\hline Factor 6/Leisure (Relaxation) Motivation & 3 & & 2.83 & 0.658 \\
\hline When I am stressful, the mall is a good place to go & & .432 & & \\
\hline I feel relax during my mall visit & & .544 & & \\
\hline $\begin{array}{l}\text { When I am alone, bored and need something to do, the mall } \\
\text { is a good place to go }\end{array}$ & & .448 & & \\
\hline Factor 7/Exploration Motivation & 4 & & 4.04 & 0.678 \\
\hline $\begin{array}{l}\text { Certain stores in the mall are fun to visit because they sell } \\
\text { products that interest me }\end{array}$ & & .589 & & \\
\hline The mall store hours are convenient & & .374 & & \\
\hline $\begin{array}{l}\text { Going to the mall is an enjoyable experience when I am with } \\
\text { friends }\end{array}$ & & .376 & & \\
\hline Mall is a good place to find out what is new & & .517 & & \\
\hline Factor $8 /$ Safety Motivation & 3 & & 4.2 & 0.664 \\
\hline I feel very secure in this shopping mall & & .510 & & \\
\hline It is very easy to find what I want always & & .459 & & \\
\hline It is a good place to shop with children & & .470 & & \\
\hline
\end{tabular}




\section{Discussions}

The discussions of the results are matched against the research questions to find answers that will eventually help achieve the research objectives.

\section{Question 1: What are the shopping visitation motivations at the mall in emerging economy?}

The extent literature review showed that several scholars have investigated into mall visitation motivations and have come out with different dimensions depending on the context. Mall visitation motivation is defined as the drivers of behaviour that bring consumers to the marketplace (mall) to satisfy their internal needs" (Jin \& Kim, 2003). Bloch et al. (1994) for instance identified seven dimensions of shopping malls that collectively explain consumers' motives for visiting malls (i.e. aesthetics, escape, flow, exploration, role enactment, social and convenience). Bellenger et al. (1977) found four basic dimensions (quality of the center, presence of related services, variety under one roof and economic convenience) while Wilhelm and Mottner (2005) found teen friendliness, number of cool mall stores, number of different kinds of mall stores, number of entertainment options, number of sports/play options and mall design.

This study found eight motivations that serve as drivers of behaviour that bring the shoppers to the mall. These motivations are safety, exploration, leisure (relaxation), escapism, convenience, flow, aesthetics and architectural and pleasure motivations.

Safety motivation: this motivation comes in the form of the shoppers having a feeling of being comfortable and secured within and around the mall. Shoppers evaluate mall's safety by its childfriendliness, secured car parks and internal security measures. Exploration motivation: this motivation has to do with the shopper learning about new trends, gathering information on new products and new trends in fashion and technology. Leisure (relaxation) motivation: this motivation has to do with the mall having the ability to provide recreational activities that comes in the form of satisfying experience. Leisure in the mall allows the shopper to have a deep and increasing appreciation of life. Escapism motivation: this motivation has to do with the malls ability to relief shoppers of boredom or loneliness, help shoppers break from daily hectic activities and offers shoppers the opportunity for pastime activities that help them get away from daily pressure.

Convenience motivation: Malls convenience ability comes in the fact that it is able to provide shoppers with the expediency to enter, exit, get assorted products and removes all anti-shopping impediments. Convenience may come in the form of mall-shopping hours, better traffic management systems and total comfort for each shopping visit. Flow motivation: this motivation describes the pleasurable state of absorption that is associated with losing track of time (Lui, 1997). Ahmed (2007) described it as the rare and desirable state attained by the shopper when inside the mall. Aesthetics and architectural motivation: these are the on-premises features of the mall in terms of the malls internal layout, manipulating structural design, interior sensory stimuli and intangible atmospherics. Pleasure motivation: the pleasure motivation of the mall shows its ability to create excitement within the shoppers and also a sense of indulgence. The mall should treat its patrons with an entertaining experience.

Question 2: What is the relationship between shopping motivation and demographic idiosyncrasies of shoppers?

The second question sought to assess the relationship between the demographic variables and the identified Mall Visitation Motivation (MVM). Since the question was seeking for the level of relationship significance, a Chi-square test was appropriate. The Chi-square test enables you to find out how likely it is that two variables are associated (Saunder et al., 2007). The Chi-square test 
calculates the probability that data could occur by chance alone by comparing with what you would expect if the two variables being compared were independent of each other. The test results are displayed in the table below.

Table 5

Relationship MVM and demographic variables

\begin{tabular}{|c|c|c|c|c|c|}
\hline \multicolumn{2}{|l|}{ Demo variable } & Pearson R & Cramer's V & $\begin{array}{l}\text { Contingency } \\
\text { Coefficient }\end{array}$ & Decision \\
\hline \multirow[t]{4}{*}{ Sex } & Value & 82.184 & 0.421 & 0.388 & Reject \\
\hline & df & 57 & & & \\
\hline & Asymp. Sig (2-sided) & 0.16 & & & \\
\hline & Approx. Sig & & 0.16 & 0.16 & \\
\hline \multirow[t]{4}{*}{ Age } & Value & 3.595 & 0.441 & 0.661 & Accept \\
\hline & df & 228 & & & \\
\hline & Asymp. Sig (2-sided) & 0.000 & & & \\
\hline & Approx. Sig & & 0.000 & 0.000 & \\
\hline \multirow[t]{4}{*}{ Education } & Value & 2.318 & .409 & .578 & Accept \\
\hline & df & 171 & & & \\
\hline & Asymp. Sig (2-sided) & 0.001 & & & \\
\hline & Approx. Sig & & 0.001 & 0.001 & \\
\hline \multirow[t]{4}{*}{ Marital status } & Value & 1.737 & 0.432 & 0.521 & Accept \\
\hline & df & 114 & & & \\
\hline & Asymp. Sig (2-sided) & 0.000 & & & \\
\hline & Approx. Sig & & 0.000 & 0.000 & \\
\hline \multirow[t]{4}{*}{ Employment } & Value & 2.266 & 0.494 & 0.572 & Accept \\
\hline & df & 114 & & & \\
\hline & Asymp. Sig (2-sided) & 0.000 & & & \\
\hline & Approx. Sig & & 0.000 & 0.000 & \\
\hline \multirow[t]{4}{*}{ Estimated income } & Value & 5.785 & 0.502 & 0.747 & Accept \\
\hline & df & 280 & & & \\
\hline & Asymp. Sig (2-sided) & 0.000 & & & \\
\hline & Approx. Sig & & 0.000 & 0.000 & \\
\hline
\end{tabular}

From the table above, it can be seen that there is NO association between MVM and sex of the respondents as it recorded a more than 0.05 significance level, which was used as the base. It therefore means that the probability of Sex and MVM occurring by chance alone is probable; which therefore means that there is no significance relationship between MVM and sex of the shopper. However, the rest of the demographic variables were significantly related with MVM as all of them were significant at 0.001 . As regards age and MVM, the overall chi-square value of 359.68 with 228 degrees of freedom (df) was recorded. The significance of 0.000 (i.e. Asymp. sig.) meant that the probability of the values in the data occurring by chance alone was less than 0.001 . It can therefore be concluded that the relationship between age and MVM was extremely unlikely to be explained by chance factors alone.

While the chi-square test is useful for determining whether there is a relationship, it does not tell you the strength of the relationship. Symmetric measures (Cramers V and Contingency coefficient) attempt to quantify this (Hair et al., 2009). The Cramer's V gives the direction and the level of significance while the Contingency coefficient gives the level of significance. The Cramer's V value of 0.441 showed that the association between age and MVM though not too strong, was positive since a strong relationship is signified by a Cramer's V value which should be greater than 0.5 (Saunders et al., 2007). The contingency coefficient of 0.66 showed somewhat strong relationship.

There was a significant relationship between education and MVM as the overall chi square value of 231.829 with $171 \mathrm{df}$ was significant at 0.001 . It can therefore be concluded that the relationship between educational level and MVM was extremely unlikely to be explained by chance factors alone. 
The Cramer's V value of 0.41 showed a positive direction of the relationship while the contingency coefficient of 0.58 showed a somewhat strong relationship. Again, there was a significant relationship between marital status and MVM as the overall chi square value of 173.67 with 114 df was significant at 0.001 . It can therefore be concluded that the relationship between marital status and MVM was extremely unlikely to be explained by chance factors alone which therefore meant that there is a significant relationship between the two variables. The Cramer's V value of 0.43 showed a positive direction of the relationship while the contingency coefficient of 0.52 showed a somewhat strong relationship.

In the same vein, there was a significant relationship between employment and MVM as the overall chi square value of 226.6 with $114 \mathrm{df}$ was significant at 0.001 . It can therefore be concluded that the relationship between marital status and MVM was extremely unlikely to be explained by chance factors alone which therefore meant that there is a significant relationship between the two variables. The Cramer's V value of 0.49 showed a positive direction of the relationship while the contingency coefficient of 0.57 showed a somewhat strong relationship. Lastly, there was a significant relationship between estimated monthly income and MVM as the overall chi square value of 578.414 with $280 \mathrm{df}$ was significant at 0.001 . It can therefore be concluded that the relationship between employment status of the shopper and MVM was extremely unlikely to be explained by chance factors alone which therefore meant that there is a significant relationship between the two variables. The Cramer's $\mathrm{V}$ value of 0.502 showed a positive direction of the relationship while the contingency coefficient of 0.75 showed a strong relationship.

Question 3: What are the shopping dimensions hierarchy effects on general on mall visitation motivation

As research question three sought to assess the shopping dimensions hierarchy effect in general on mall visitation motivation, two statistical analyses was performed. Firstly, a comparison of the means of the various factors could tell which of the motivations respondents rated higher. However since the comparison of the factors means cannot tell the real effect on the overall motivation to the mall, a multiple regression analysis was performed. The regression analysis's $\beta$ values tell the direction and the level of the effect of each factor.

\section{Table 6}

Descriptive Statistics of MVM Factors

\begin{tabular}{llll}
\hline Factors & $\mathrm{N}$ & Mean & Std. Deviation \\
\hline Pleasure & 465 & 3.5500 & .82168 \\
Aesthetics and Architectural & 467 & 3.9631 & .60519 \\
Flow & 467 & 3.3233 & .77999 \\
Convenience & 467 & 4.0735 & .62767 \\
Escapism & 467 & 3.6955 & .69791 \\
Leisure & 467 & 2.8323 & .78292 \\
Exploration & 467 & 4.0482 & .55428 \\
Safety & 467 & 4.2027 & .70985 \\
Valid N & 465 & & \\
\hline
\end{tabular}

According to the descriptive analysis of the MVM factors, the most significant motivation for the mall visit is safety (4.20) followed by convenience (4.07), exploration (4.05), aesthetics and architectural (4.00), escapism (3.70), pleasure (3.55), flow (3.32) and leisure (2.83). But as indicated earlier, these ranking does not tell the effect on the overall mall visitation motivation, therefore the regression analysis was needed. 
The relationship of all the variables in the casual model was assessed based on the research question and the results displayed in the regression table. The multiple coefficient $(R)$ is 0.980 , suggesting reasonably good correlation between all the influencing factors taken together and MVM, but the adjusted $R^{2}$ figure of 0.960 suggests that they can explain $96 \%$ of the variance, leaving only $4 \%$ unexplained and the analysis of variance was statistical significance at 0.000 , and the analysis of relationships between all the influencing factors and mall visitation can be accepted.

Table 7

Regression Analysis of MVM Factors

\begin{tabular}{|c|c|c|c|c|c|}
\hline \multirow{3}{*}{$\begin{array}{l}\text { Model } \\
1 \text { (Constant) }\end{array}$} & \multicolumn{2}{|c|}{ Unstandardized Coefficients } & \multicolumn{2}{|c|}{ Standardized Coefficients } & \multirow{3}{*}{$\begin{array}{l}\text { Significance } \\
.001\end{array}$} \\
\hline & $B$ & $S E$ & $\beta$ & $t$ & \\
\hline & .122 & .037 & & 3.265 & \\
\hline Pleasure & .140 & .006 & .268 & 24.270 & $.000 * * *$ \\
\hline $\begin{array}{l}\text { Aesthetics and } \\
\text { Architectural }\end{array}$ & .122 & .008 & .172 & 15.736 & $.000 * * *$ \\
\hline Flow & .118 & .006 & .215 & 20.230 & $.000 * * *$ \\
\hline Convenience & .097 & .008 & .142 & 12.529 & $.000 * * *$ \\
\hline Escapism & .187 & .007 & .304 & 25.846 & $.000 * * *$ \\
\hline Leisure & .082 & .005 & .150 & 15.642 & $.000 * * *$ \\
\hline Exploration & .106 & .009 & .137 & 11.272 & $.000 * * *$ \\
\hline Safety & .105 & .007 & .173 & 15.969 & $.000 * * *$ \\
\hline $\begin{array}{l}\text { Note: Dependent V } \\
R=.96 \quad R^{2}=0.90\end{array}$ & $\begin{array}{l}\text { itation } \\
0.960\end{array}$ & $F=1389.230$ & Sig c & & \\
\hline
\end{tabular}

A person's mall visitation motivation can be positively influenced by all the factors as significant predictors of MVM. Considering the level of significance of those factors, the said table still shows that all the factors were significant (sig. of 0.000). In general, escapism (0.304), favourably influenced the mall visitation motivation most followed by pleasure $(0.268)$, flow $(0.215)$, safety (173), aesthetics and architectural (0.172), leisure (0.150) and the least influential being exploration (0.137).

\section{Conclusion and implication}

The study revealed that there are eight (8) key mall visitation motivations that will attract Ghanaian shoppers to the mall. These distinctive motivations are safety, exploration, leisure (relaxation), escapism, convenience, flow, aesthetics and architectural and pleasure motivations. Generally, escapism favourably influences the shoppers mall visitation motivation most, followed by pleasure, flow, safety, aesthetics and architectural, leisure and the least influential being exploration. This therefore mean that the shoppers in Ghana, are more likely to see the mall as an escape route from the daily hectic affairs and as a place to kill their boredom the find pleasure than as a place for finding new things or for the mall's architectural beauty. The study has also shown that shopping motivation has a positive relationship with the demographic idiosyncrasies of shoppers to a very large extent. The study showed that only sex of the shopper relates significantly with their mall visitation motivation factors. The other demographic variables such as age, educational level, marital status, employment status and monthly income relates very significantly with the shoppers mall visitation motivation.

There is rising competition on the front of the retailing industry where the malls and the shops within the malls belong. It therefore behooves on these retail formats to be innovative and customer-centered in order to enjoy the better part of the market. Mall management must be cognizant of the needs and wants of the targeted consumers to build and maintain market share. The results of this study have several implications that should be of benefit to the retailing industry, and mall management. Shopping malls have become social and recreational centers where people go for multiple purposes: shopping, recreational pursuits, entertainment, meeting friends, simply browsing around, and so on. Therefore, developers of malls must adapt to the fact that malls have evolved into something more 
than simply a place for buying products. Shopping malls, that could offer exciting stores with enticing product assortments, multitudinous entertainment and "experiential" opportunities, combined with modern and attractive designs and facilities will be necessary to attract more people.

Escapism was the most influencing mall motivation factor for shoppers' mall visitation. This therefore means that shoppers find the mall as a place to deal with their loneliness and boredom, get relief from stressful activities during the day and use as an avoidance of traffic. Mall developers in Africa and specifically in Ghana, must therefore take key note of this fact and include the dimensions and properties of the mall being able to serve the "getaway" needs of the mall shoppers. Exploration, leisure, flow and convenience dimensions were also preferred by the shoppers. The shoppers favoured a wide assortment of products, one-stop shopping, and an enjoyable place to socialize with friends. Mall management of the tenant and service mix should be used as a strategic tool in attracting shoppers to contemporary African malls. Aesthetic factors were also preferred by the shoppers. Statements related to interior design of the malls, decorations, and lighting was found to have high preference scores. As such, mall management should make sure that their mall atmospherics offer a mall environment that is pleasing to multiple senses, to ensure it is conducive for shoppers to stay and spend more of their time and money. Managing atmospherics is a strategic task, affecting success in positioning and differentiation.

Segmentation based on demographic variables of consumers has been espoused by many researchers over the years (Lin \& Kim, 2001; Mai \& Zhao, 2004). In this study, it has come to light that mall shoppers in a developing economy like Ghana can have its market well segmented on the demographic variables such as age, educational level, employment status, and estimated monthly income. These variables were favourably related to the mall visitation of shoppers and therefore can serve as a good measure of segmentation for mall planners and potential tenants of malls in developing economies must seriously consider. Tenants of the malls in Africa must be particular about the age, educational level, employment status, and estimated monthly income about their target market as they offer important managerial and marketing insight. Though the study sought to investigate the developing economies within the sub-Saharan Africa, the findings are generally based on shoppers in Ghana which therefore must guide users of the findings in its application to other subSaharan African countries. Future research should also consider a broader demographic profile representing multiple geographical locations in Africa as well as other region given that consumer' shopping-related perceptions and expectations are likely to differ across countries or cultures throughout the world. Future research covering wider perspectives is desirable to enable comparisons, benchmarking and setting standards. With many mall developers and mall managers now operating as MNCs (multi-national corporations), this international perspective is particularly important.

\section{References}

Ahmed, Z. U., Ghingold, M. and Dahari, Z. (2007). Malaysian shopping mall behaviour: an exploratory study. Asia Pacific Journal of Marketing and Logistics, 19(4), 331-348.

Arnold, M.J., \& Reynolds, K.E. (2003). Hedonic shopping motivations. Journal of Retailing, 79, 77 95.

Bellenger, D.N., Robertson, D.H., \& Greenberg, B.A. (1977). Shopping center patronage motives. Journal of Retailing, 52(2) 29-38.

Beynon, M.J. (2010). Gender differences in supermarket choice - An expositional analysis in the presence of ignorance using CaRBS. European Journal of Marketing, 44(1/2) 267-290

Bloch, P.H., Ridgway, N.M., \& Dawson, S.A. (1994). The shopping mall as consumer habitat. Journal of Retailing, 70(1) 23-42.

Chetthamrongchai, P., \& Davies, G. (2000). Segmenting the market for food shoppers using attitudes to shopping and to time. British Food Journal, 102(2) 81-101.

Churchill, G.A. (1995). Marketing Research: Methodological Foundations. $6^{\text {th }}$ ed. Fort Worth: Dryden Press. 
Dennis, C., Newman, A., \& Marsland, D. (2005). Objects of Desire: Consumer Behaviour in Shopping Centre Choices. Palgrave, London.

Dholakia, R.R. (1999). Going shopping: key determinants of shopping behaviours and motivations. International Journal of Retail \& Distribution Management, 27(4) 154-65.

Dholakia, R.R. (1999). Going shopping: key determinants of shopping behaviours and motivations. International Journal of Retail \& Distribution Management 27(4) 154-65.

Dogu, U. and Erkip, F. (2000). Spatial factors affecting wayfinding and orientation: a case study in a shopping mall. Environment and Behaviour, 32(6) 731-55.

El-Adly, M.I. (2007). Shopping malls' attractiveness: a segmentation approach. International Journal of Retail \& Distribution Management, 35(11) 936-50.

Hair, J. F., Jr., Babin, B., Money, A. H., \& Samouel, P. (2003). Essentials of business research methods. New York: Wiley.

Haytko, D.L. and Baker, J. (2004). It's all at the mall: exploring adolescent girls' experiences", Journal of Retailing, 81(1) 67-83.

Holme, I. M., \& Solvang, B. K. (1997). Forskningsmetodik: om kvalitativa och kvantitativa metoder, Lund: Studentlitteratur

Howard, E. (2007). New shopping centres: is leisure the answer? International Journal of Retail \& Distribution Management, 35(8), 661-72.

Humphrey, J. (2007). The Supermarket Revolution in Developing Countries: Tidal Wave or Tough Competitive Struggle? Journal of Economic Geography, 7 433-450.

Hunter, G. L. (2006). The role of anticipated emotion, desire, and intention in the relationship between image and shopping center visits. International Journal of Retail \& Distribution Management, 34(10), 709-721

Jin, B., \& Kim, J.-O. (2003). A typology of Korean discount shoppers: shopping motives, store attributes, and outcomes. International Journal of Service Industry Management, 14(3/4) 396-419.

Kaufman, C.F. (1996). A new look at one-stop shopping: a TIMES model approach to matching store hours and shopper schedules. Journal of Consumer Marketing, 13(1) 4-52.

Kim, Y.-K. (2002). Consumer value: an application to mall and internet shopping. International Journal of Retail \& Distribution Management, 30(12), 595-602.

Kotler, P., \& Keller, P. (2006). Marketing Management. Prentic Hall, New Jersey

Kowinski,W.S. (1985). The Malling of America.William Morrow\& Co., New York, NY.

Kumar, R. (1996). Research Methodology- A Step by Step Guide for Beginners. Sydney: Addison Wesley.

LeHew, M.L.A., \& Fairhurst, A.E. (2000). US shopping mall attributes: an exploratory investigation of their relationship to retail productivity. International Journal of Retail \& Distribution Management, 28 (6), 261-79.

Loudon, D.L., \& Bitta, A.J.D. (1993). Consumer Behaviour: Concepts and Applications, $4^{\text {th }}$ ed., McGraw-Hill, New York, NY.

Lui K. F. (1997). Shopping behaviour in Kuala Lumpur shopping malls. Universiti Putra Malaysia.

Mai, L.-W., \& Zhao, H. (2004). The characteristics of supermarket shoppers in Beijing. International Journal of Retail \& Distribution Management, 32 (1), 56-62.

McGoldrick, P. (2002). Retail Marketing. $2^{\text {nd }}$ ed., McGraw-Hill, Maidenhead.

Michon, R., Chebat, J.C. \& Turley, L.W. (2005). Mall atmospherics: the interaction effects of the mall environment on shopping behaviour. Journal of Business Research, 58 (5), 576-83.

Millan, E. S., \& Howard, E. (2007). Shopping for pleasure? Shopping experiences of Hungarian consumers. International Journal of Retail \& Distribution Management 35 (6), 474-487

Mitchell, V.-W., \& Walsh, G. (2004). Gender differences in German consumer decision-making styles. Journal of Consumer Behaviour, 3(4), 331-46.

Newberry, R.C., Klemz, B.R., \& Boshoff, C. (2003). Managerial implications of predicting purchase behaviour from purchase intentions: a retail patronage case study. Journal of Services Marketing, 17(6), 609-20. 
Ng, C.F. (2003). Satisfying shoppers' psychological needs: from public market to cyber-mall. Journal of Environmental Psychology, 23(4), 439-55.

Nicholls, J.A.F., Li, F., Kranendonk, C.J., \& Roslow, S. (2002). The seven year itch? Mall shoppers across time. Journal of Consumer Marketing, 19 (2), 149-65.

Nunnally, J.C. (1978). Psychometric Theory. $2^{\text {nd }}$ ed., McGraw-Hill Book Company, New York, NY.

Ooi, J. T. L., \& Sim, L.-L. (2007). The magnetism of suburban shopping centers: do size and Cineplex matter. Journal of Property Investment \& Finance, 25(2), 111-136

Othman, M.N., \& Lim, S.H. (1997). Consumer behavior in shopping malls: a study of urban Malaysian consumers. Malaysian Journal of Consumer \& Family Economics, 79-90.

Parasuraman, A., Zeithaml, V. A., \& Berry, L. L. (1988). SERVQUAL: A Multiple-Item Scale for Measuring Consumer Perceptions of Service Quality. Journal of Retailing, 64(1), 12-40.

Perner, L.E. (1998). Optimal stimulation level as a moderator of 'high-low' and EDLP pricing effectiveness. unpublished doctoral dissertation, University of Southern California, Los Angeles, CA.

Peter, J.P., \& Olson, J.C. (1994). Understanding Consumer Behaviour, Irwin Inc, Homewood, IL.

Rajamma, R. K., Paswan, A. K. and Hossain, M. M. (2009). Why do shoppers abandon shopping cart? Perceived waiting time, risk, and transaction inconvenience. Journal of Product \& Brand Management, 18(3).188-197

Raju, P.S. (1980). Optimum stimulation level: its relationship to personality, demographics, and exploratory behaviour. Journal of Consumer Research, 7, 272-82.

Reardon, T, Henson, S, \& Berdegue, J. (2007). Proactive fast-tracking diffusion of supermarkets in developing countries: implications for market institutions and trade. Journal of Economic Geography, 7(4) 399-431.

Reardon, T., \& Berdegue, J.A. (2006). The Retail-led Transformation of Agrifood Systems and its Implications for Development Policies, Rimisp-Latin American Center for Rural Development.

Rintamaki, T.K.A., Kuusela, H., \& Spence, M.T. (2006). Decomposing the value of department store shopping into utilitarian, hedonic and social dimensions: evidence from Finland", International Journal of Retail \& Distribution Management, 34(1), 6-24.

Robson, C (2002). Real world research. $2^{\text {nd }}$ ed, Oxford, Blackwell

Saunders, M., Lewis, P., \& Thornhill, A. (2003). Research methods for business students, $3^{\text {th }}$ ed. Prentice Hall, UK

Sit, J., Merrilees, B., \& Birch, D. (2003). Entertainment-seeking shopping centre patrons: the missing segments. International Journal of Retail \& Distribution Management, 31(31), 80-94.

Soars, B. (2009). Driving sales through shoppers' sense of sound, sight, smell and touch, International Journal of Retail \& Distribution Management, 37(3), 286-298

Solomon, M.R. (1994). Consumer Behaviour, 2nd ed., Allyn Bacon

Tauber, E.M. (1972). 'Why do people shop? Journal of Marketing Management, Fall, 58-70.

Taylor, S. L. and Cosenza, R. M., (2002). Profiling later aged female teens: mall shopping behaviour and clothing choice. Journal of Consumer Marketing 10(5), 393-408

Torkildsen, G. (1992). Leisure and Recreation Management. E\&FN Spon, London.

Tull, D.S \& Hawkins, D.I. (1990). Marketing Research. 5th Ed. New York: Macmillian Publishing Company.

Underhill, P. (1999). Why We Buy? The Science of Shopping, Simon Schuster, New York, NY.

Underhill, P. (2005). Call of the Mall. Simon Schuster, New York, NY.

Wakefield, K., \& Baker, J. (1998). Excitement at the mall: determinants and effects on shopping response. Journal of Retailing, 74(4), 515-539.

Wilhelm, W.B., \& Mottner, S. (2005). Teens and shopping mall preferences: a conjoint analysis approach to understanding the generational shift toward an experience economy. Journal of Shopping Center Research, 12(1), 23-52.

Wong, G.K.M., Lu, Y., \& Yuan, L.L. (2001). SCATTR: an instrument for measuring shopping center attractiveness. International Journal of Retail \& Distribution Management, 29(2), 76-86. 
Wood, M. (1998). Socio-economic status, delay of gratification, and impulse buying. Journal of Economic Psychology, 19, 295-320.

Woodruffe-Burton, H., Eccles, S., \& Elliott, R. (2002). Towards a theory of shopping: a holistic framework. Journal of Consumer Behaviour, 1(3), 256-66.

Yavas, U. and Babakus, E. (2009). Modeling patronage behaviour: a tri-partite conceptualization, Journal of Consumer Marketing 26(7), 516-526 